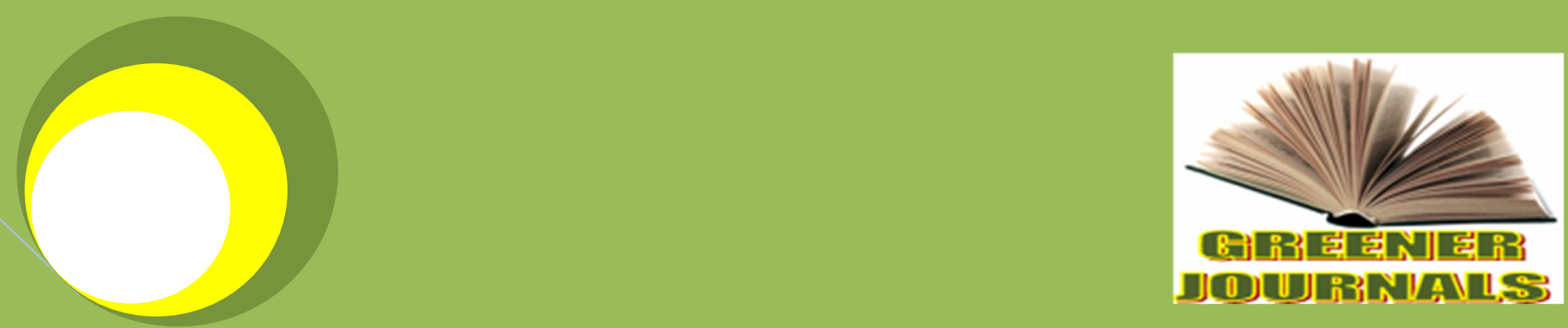

Greenerilournal of Educational Research

ISSN: 2276-7789 ICV: 6.05

Submitted: 19/06/2017

Accepted: 23/06/2017

Published: 28/06/2017

DOI: http://doi.org/10.15580/GJER.2017.4.061917078

Empirical Look at the

Use and Impact of Smart

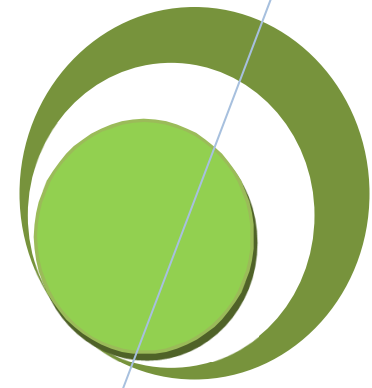

Phones by Medical

Students for Laboratory/

Educational Purposes at

Ambrose Alli University,

Ekpoma, Edo State

By

Ikenwe Iguehi Joy (Cln)

Idhalama Ogagaghene Uzezi (Cln)

Inegbenojie O. Emmanuel 


\title{
Empirical Look at the Use and Impact of Smart Phones by Medical Students for Laboratory/ Educational Purposes at Ambrose Alli University, Ekpoma, Edo State
}

\section{Ikenwe, Iguehi Joy (Cln $)^{1 *}$; Idhalama, Ogagaghene Uzezi $(\mathrm{Cln})^{2}$ and Inegbenojie, Osemudiamen Emmanuel ${ }^{3}$}

\author{
${ }^{1}$ Ambrose Alli University, Ekpoma-Edo State, Ikenweiguehi@Yahoo.Com 08037521224 \\ ${ }^{2}$ Ambrose Alli University, Ekpoma-Edo State, Idhalamao@Gmail.Com 07064647292 \\ ${ }^{3}$ Ambrose Alli University, Ekpoma-Edo State
}

*Corresponding Author’s E-mail: Idhalamao@ gmail. com; Phone: 07064647292

\begin{abstract}
Usage of Smartphone's in the medical profession has become a pivotal area of research in recent times. In as much as Smartphone's have a great potential to facilitate communication and sharing of information amongst medical students. This study examined the use and impact of Smartphone's by medical students in Ambrose Alli University, Ekpoma. The study adopted survey research design. The population of the study comprised 2,304 medical students, a sample of 230 was drawn from the population and Accidental sampling technique was used. Questionnaire was used for data collection and data analyzed using descriptive statistics and mean statistics. The study revealed a high level of awareness and use of Smartphone's by medical students. There is a tremendous impact of Smartphone's on the academic work of medical students and they use Smartphone's for carrying out assignments, downloading E journals, downloading medical apps and e textbooks, browsing the internet amongst others. It was also revealed that irregular power supply, high risk of radiation when using Smartphone, insecurity of usage, operational difficulties and lack of technical experts on repair within campus are some challenges encountered by medical students in Ambrose Alli University, Ekpoma, in the use of Smartphone's. It was recommended that Smartphones technicians can be employed within campuses to repair faulty phones, Nigerian Communication Commission (NCC) should monitor service providers to ensure affordable subscription rate to students, tertiary institutions should try to provide free Wifi for tertiary students issue of poor power supply should be looked at most especially within campuses etc.
\end{abstract}

Keywords: Smartphone's, Smartphone usage, Smartphone impact, Medical Students.

\subsection{INTRODUCTION}

Technological revolutions have made communication and sharing of information take a new dimension amongst students especially for educational purposes. A recent major technological revolution that has influence positively the way students communicate and share information is through smartphones. Elogie, Ikenweand Idubor(2015) categorically stated that, smartphones can be considered the most ubiquitous technology amongst the youth as it allows users to connect to one another socially. Furthermore, it can be used for personal, educational ,business, entertainment and a plethora of other purposes.

Rouse(2013) indicated that, a smartphone is a cellular telephone with an integrated computer and other features not originally associated with telephones, such as an operating system, web browsing and the ability to run software applications. The first smart phone was IBM'S Simon, which was presented as a concept device (rather than a consumer device) at the 1992 COMDEX computer industry trade show. Fuxin (ND) noted that, in the early inception of mobile technology development, mobile phones were reserved for the elite, primarily used by middle and upper class people (wealthy people). The term smart phone is designed because of the work these phone domultipurpose. This is owing to the fact that over the years phones are becoming more advanced and enhanced hence the name smart phone. Pitch Fred (2010), critically looked at top five most accepted definitions of smart 
phone, and resolved that there was no single accepted definition. This is due to the constantly evolving nature of mobile phone technology. At the end of Litchfied study in 2010, he argued that; a smart phone is that phone that runs an open operating system and is permanently connected to the internet. Smart phone have come to stay as they now serve as various means of boosting learning.

The use of smart phone is arguably taking a centre stage in academics and other sectors. To this end, Sarwar and Soomro (2013) aver that smartphone has impacted almost all the walk of human life. They submitted that the prominent areas, where impacts of smart phones are obvious include business, education, health and social life. Today, globalization has changed so many things, for instance the way we dress, behave, learn, teach e.t.c. This globalization is also extended with the advent of ICT where smart phone is accommodated in the learning system, smart phone has major and important role to play in the light of the above. Taylor and Harper (2013), portray that smart phones and its use have special place and impact in student life and academic performance specially. In ensuring effective academic performance of students, teacher should encourage their wards to be more proactive in taking advantage of all available information and communication technology (ICTs); smart phone inclusive. Going by recent studies despite its few negative impacts smart phone has a lot of positive impacts in the life of academic journey of student, across the board. This therefore means that it is as well very useful to medical students.

A medical school is a tertiary educational institution or part of such an institution that teaches Medicine and awards a professional degree for physicians and surgeons. Such medical degrees include the Bachelor of medicine, bachelor of surgery (MBBS, MBCHB , BMBS), Doctor of medicine (MD), or Doctor of Osteopathic Medicine (DO). Many medical schools offer additional degrees such as a doctor of philosophy, masters of degree, a physician assistance program, or offer post-secondary education. (Medical school- wikepedia, 2017). In a similar vein, a medical student is that student who is enrolled at a medical school, who is training to become a physician.

The smart phone is used as means of interactions among people in which they create, share and exchange information and ideas in virtual communities and networks. (Blumstock \& Eagle, 2010). It also uses a group of internet-based applications that build on the ideological and technological foundations of web 2.0 that allows the creation and exchange user generated content. (Mayer \& Mereno, 2003).According to Kohe and Wan (2014), they aver that there are medical apps perceived by medical students to help improve their clinical decision making which also save time, allow fast access to natural clinical practice guidelines, allow faster access to common laboratory reference values, help in making differential diagnosis, enable useful medical related calculation, allow faster accesses to reliable source of knowledge.

On his own part, Bruce (2010), opine that, medical students can also use smart phones to access links, relevant websites, videos, course materials and also access course materials so that students can learn at a convenient time and place. This shows quite a positive impact of smart phone on medical student academic performances. Notwithstanding, some researchers are of the opinion that smart phone have caused more harm than good. Rabiu, Muhammed, Umaru and Ahmed (2016) submit that internet/ smart phone access has exposed many medical students to different kinds of contents. Just of recent, the availability of different kinds of affordable and inexpensive android mobile phones made it easy for the students to have access to different types of social media and pornographic sites where they access, download, exchange and watch pornographic films or different sexual orientations from all over the world.

The situation is worsened by the ignorance and careless attitude of parents who are mostly oblivious of and careless about those young one's needs and the challenges. Also, guidance and counselling services are either absent or inactive in most medical schools and the school lectures are not helping the situation (Taylor and Harper, 2003). Most students today are highly influenced by what they watch on those several media sites with their smart phones, and one can easily see the consequences in their academic performance and life styles. Rabiu et al (2016) report that the continuous downwards, spiralling in academic performance, the rise in cases of dropouts, the increase in most of the unacceptable, immoral and antisocial behaviors perpetrated by students in secondary schools today, which include truancy, massive failures, exam malpractices, improper dress codes, indiscriminate sexual relationships with opposite sex and most violent behaviours, can mainly be attributed to the influence of the mobile and smart phones.

\subsection{Statement of the Problem}

Smart phones are presently gaining popularity and full acceptability among students both in secondary and tertiary institutions. Observers and researchers are therefore divided if actually these devices are of benefits to the student. Some researchers argue that the place of smart phone in academic performance cannot be underestimated; others argued that it is mere distraction in disguise to students. However, the medical students as focus of this study are selected owing to the fact that they are expected to be more serious and studious because of the peculiar nature of their profession. They are supposed to use smart phones to further broaden their knowledge and intellect; but to the dismay of so many the standard of education in Nigeria (medical schools inclusive) have consistently dropped over 
the years. To this end, the researchers will critically study the use and impact of smart phones in medical student learning process.

\subsection{Objective of the Study}

The specific objectives of the study are to;

1. Find out the level of awareness and use of smart phone by medical students for their academic works.

2. Find out some of the medical resources and services smart phones are used for by medical students for their academic works

3. Determine the impact of smart phone on academic performance by medical students.

4. Identity the major problems encountered by medical students in using smart phones in gathering information for their academic works.

\subsection{REVIEW OF RELATED LITERATURE}

\subsubsection{Awareness and Use of Smartphones}

Cell/ smart phones are seen to be most speedily emerging technologies in the human race (Robello, 2010). Studies have shown that awareness and use of smart phones have continued to grow astronomically. According to Hakoama \& Hakoyama (2010), there has been quite an enormous amount of popularity of cellular/ smart phones in youngsters' generation within a short span of time Youth and students are more versatile in the sense of smart phones therefore making its used and access more interesting. In this light, Elogie, Ikenwe and Idubor 2015), opined that smartphones will presumably allow students have immediate access to information, communication applications, ability to shop online, mobile banking and entertainment. On the other side of the story, tutors and teachers have reservations about the use of smart phone by medical students/ youngsters. They believed that the use of smart phones by students at school could restrain them from their education and this stands as a hurdle to their academic pursuit (John \& Kritsons, 2007).

Koh and Wan (2014), studied medical students perceptions regarding the impact of mobile medical application on their clinical practices; through the use of questionnaire, they surveyed 155 first year medical students of the international medical university, Malaysia, about the demographic parameters, types of smart devices owned and the medical apps used, the frequency and purposes of usage of the apps and the problems encountered in using mobile devices. The study found that there is high prevalence of smart devices and medical apps usage with positive perception regarding its usage and impact on their clinical practice. And they recommended medical schools to encourage the use of smart phones and medical apps among medical students with strategies put in place to safe guard patients confidentiality.

The medical students can use smart phones to literally add colour to their studies, certainly, it is not just for making and receiving calls. The use of smart phone is not limited to speaking alone; it is being used for videos, recording information and transmitting it to phone or computer as was being done by a computer, mobile banking, and payment surveillance. According to Boruff and Stories (2014), smart phones are commonly used by medical students to find and gather medical and health information that help capacity building in health education.

Hanson et. al. (2011) averred this generation has grown up in a technologically rich world, using mobile phones on chat rooms, electronic mails, computer games, and listening to music and watching TV and videos. According to Tindell and Bohlander (2012) in an emergency, text messages can be sent directly to students' phones informing them of the source of the emergency and instructions on how to respond.

Oksman, (2010) stressed that in addition to new media, the traditional media such as newspapers, radio and television are also made available on the smartphone through the Internet. Dean, (2010) Ryerson University students' experience and expectancy with their mobile library site, "searching for articles, reading electronic Books, checking out books, and contacting librarian or getting research help" were students' top future request. It further stressed that text messaging and e-mailing are two of the most commonly used functions on smartphones among college students, followed by reading news, watching videos and reading books.

\subsubsection{Impact of Smartphones to Medical Students}

Jubien (2013), mentions one finding about how smart phones are influencing and changing educational practices, for example, changes in the way to gather information, to receive instructions from teachers, to do homework, to collaborate with class mates, among others. Cellphones as discussed by Hingorani, et al. (2012) can access social 
media sites, such as Facebook and Twitter in addition to the traditional use of calling and sending text messages.

Universities also used cellular phones to advertise campus events and happenings, to promote the university brand among their students and to stay connected for a safer campus. Balakrishnan \& Raj (2012), female students in Malaysia and Australia use their phones as a security device to contact others when they are in danger.

John (n.d) submits that smartphones are popular among medical students for the applications that they offer. Students find it quite easier to communicate with people in a different way and also access different things with the features that smartphones support. Students enjoy a lot of benefits in various forms of their daily routine. They also get things done in quick time in an efficient manner. Smartphones offer: better means of communication, learning options to users great exposure to the latest thing, ways to personally, academically develop, simple ways to access applications, ideas to succeed in academics and platform to grow along with technology.

\subsubsection{Problems Encountered by Medical Students in the Use of Smartphones}

On the other hand of challenges, Kuznekoff and Titsworth (2013), observed that students who use their smart phones during class lectures tend to write down less information, recall less information, and perform worse on a multiple choice test than those students who abstain from using their mobile phones during class. Smart phones usage by medical students have more other challenges despite the fine picture earlier painted. Even though smart phones are powerful with amazing speed, their screens remain comparatively small and navigations is also difficult thus, making users lose more time in searching for information.

According to Baidu (2015), there are seven common smart phone issues that get in the way of enjoying your many devices. The report detailed three particular categories' that show when these issues typically occur: batteryrelated, speed-related, and storage space-related. He further listed some of the problems with smart phones to include but not limited to: overheating, too much trash, slow online speeds, not enough space, phone crashes, slow response time and finally, not enough standby time.

Tindell and Bohlander (2012) embedded the survey of 269 college students from a private university in north-eastern Pennsylvania to gain understanding of the use and abuse of cell phones in a college classroom setting, and to potentially aid in policy-making decisions. The researchers found that students are spending time texting and are not paying attention to the class lecture.

Elder (2013) studies explored college students self-reported cell phone usage and beliefs and investigated the effect on student learning. Elder (2013) reported that $85 \%$ of university faculty and students both said cellphones were distracting and $45 \%$ noticed that vibrating phones in the classrooms were problematic. According to Hanson, Drumheller, Mallard, McKee and Schlegel (2011) students in the library used email, instant messaging and websurfing rather than checking the library's online resources. Although students want to make academics a priority, they have a difficult time balancing their school life with their need for financial and social support.It was found that students focus more on updating their Facebook status than downloading their homework assignments. There are other smart phone challenges like: incessant virus attack, high cost of data subscription, irregular/ unstable power supply for charging of battery, lack of experts to repair e.t.c

\subsection{METHODOLOGY}

This Study adopted Survey research design. The population comprised 2,304 medical students from four departments in the Faculty of Basic Medical Sciences,Ambrose Alli University, Ekpoma as represented below;

\begin{tabular}{|l|l|l|l|l|l|l|}
\hline S/N & DEPARTMENT & $\mathbf{1 0 0}$ LEVEL & 200LEVEL & 300 LEVEL & 400 LEVEL & 500LEVEL \\
\hline A & Anatomy & 127 & - & - & - & - \\
\hline B. & Nursing Science & 185 & 139 & 90 & 110 & 85 \\
\hline C. & Medical laboratory & 307 & - & 62 & 55 & 183 \\
\hline D & Physiology & 296 & 271 & 198 & 196 & - \\
\hline
\end{tabular}

SOURCE: ICT Unit, A.A.U., 2016.

A sample size of 230 was drawn from the total population $(2,304)$ and accidental sampling technique was used. The research instrument adopted for this study was questionnaire titled " Use and Impact of Smartphones by medical students. The questionnaire comprised 2 major sections. Section A was aimed at gathering data on demographic profile. While section B was to elicit information on the variables. Likert Scale was used to measure the "use and impact of smartphones and the instrument was validated by three professionals. Descriptive statistics (such as frequency and simple percentage) and mean statistics was used in analyzing the data collected for the study . 


\subsection{DATA ANALYSIS}

\section{Demographic Characteristics of Respondent}

The demographic of respondents are analyzed below;

\subsubsection{Questionnaire Distribution}

\begin{tabular}{|l|l|l|}
\hline Options & Questionnaire & Percentage \% \\
\hline Retrieved and used Questionnaire & 213 & 92.2 \\
\hline Unreturned questionnaire & 18 & 7.8 \\
\hline Total & 230 & 100 \\
\hline
\end{tabular}

Source: field survey 2016.

From the above, 213 copies of the 230 questionnaire distributed representing $92.2 \%$ were retrieved while $18(7.8 \%)$ were un-returned. Hence, 213 copies of the questionnaire were retrieved and used in the study.

\subsubsection{Department of Respondents}

\begin{tabular}{|l|l|l|l|}
\hline S/N & Department & Respondent & Percentage \% \\
\hline 1 & Anatomy & 20 & 9.4 \\
\hline 2 & Nursing & 40 & 18.8 \\
\hline 3 & Medical laboratory & 36 & 16.9 \\
\hline 4 & Physiology & 117 & 54.9 \\
\hline & Total & 213 & 100 \\
\hline
\end{tabular}

The table above shows the number of respondents in respect to their departments. According to the results, it was revealed that majority of respondents representing, $117(54.9 \%)$ were from physiology, 40 (18.8\%) were from nursing $36(16.9 \%)$ were from medical laboratory while 20 representing $9.4 \%$ are from anatomy.

\subsection{RESEARCH QUESTIONS}

\section{Research question 1: Are you aware of smartphone and do you use one?}

Table 4.2: Respondents opinion on whether they own/ use smartphone for their academic works

\begin{tabular}{|l|l|l|l|l|l|}
\hline & Awareness and use of smart phones & Yes & $\%$ & NO & $\%$ \\
\hline & & & & & \\
\hline 1 & Medical student awareness of smart phone & 213 & 100 & & \\
\hline 2 & Medical students that use smart phone & 206 & 96.7 & 7 & 3.2 \\
\hline & Total & & 196.7 & & 3.2 \\
\hline
\end{tabular}

From the table above, results show that majority of the students $213(100 \%)$ are aware of smart phones and 206 $(96.7 \%)$ of the respondents use smart phone for their academic work while only $3.2 \%$ of them neither have nor use smart phones for their academic work. This shows that there is high level of awareness and use of smart phone by medical students. Therefore, only those that used smart phones $206(96,7 \%)$ was used for the analysis. $n=206$. 
Research Question 2: what are the medical resources and services smart phones used for by medical students for their academic works?

\begin{tabular}{|c|c|c|c|c|c|c|c|c|}
\hline $\mathrm{S} / \mathrm{N}$ & Response item & SA & A & $\mathrm{D}$ & SD & $\mathrm{F}$ & Mean & Remark \\
\hline 1 & Browsing internet & 142 & 62 & 2 & - & 758 & 3.7 & Agree \\
\hline 2 & Downloading e-text books & 135 & 60 & 8 & 3 & 739 & 3.6 & Agree \\
\hline 3 & Taking notes in class/lab & 122 & 73 & 7 & 4 & 723 & 3.5 & Agree \\
\hline 4 & Carrying out assignment & 135 & 70 & 1 & - & 752 & 3.7 & Agree \\
\hline 5 & Downloading medical apps & 119 & 85 & 2 & 0 & 735 & 3.5 & Agree \\
\hline 6 & Downloading medical e-journals & 119 & 76 & 9 & 2 & 724 & 3.5 & Agree \\
\hline 7 & Recording audio/videos lectures & 127 & 64 & 12 & 3 & 727 & 3.5 & Agree \\
\hline 8 & Accessing online lectures & 37 & 19 & 87 & 63 & 442 & 2.1 & Disagree \\
\hline 9 & $\begin{array}{l}\text { Accessing the medical college library } \\
\text { resource/services }\end{array}$ & 4 & 37 & 98 & 67 & 386 & 1.9 & Disagree \\
\hline 10 & Social networking & 92 & 100 & 13 & 1 & 695 & 3.3 & Agree \\
\hline 11 & For leisure and entertainment & 122 & 73 & 5 & 6 & 723 & 3.5 & Agree \\
\hline
\end{tabular}

Source: field survey 2016

The table above reveals that majority of the respondents agreed that they use their smart phones in browsing the internet (3.7), carrying out their assignment (3.7), downloading e- text books (3.6), medical app (3.5), medical ejournal (3.5), taking notes in class/lab (3.5), for leisure and entertainment (3.5) and social networking (3.3). it also showed that a good number of respondents indicated that they do not use their smart phones to access the medical college library resource/ service (1.9), accessing online lectures (2.1) respectively.

Research Question 3: What is the impact of smart phones on academic performance of medical students?

\begin{tabular}{|l|l|l|l|l|}
\hline & Positive impact & Negative impact & Little impact & No impact \\
\hline Medical student & $183(88.8 \%)$ & - & $16(7.8 \%)$ & $7(3.4 \%)$ \\
\hline Total & $183(88.8 \%)$ & - & $16(7.8 \%)$ & $7(3.4 \%)$ \\
\hline
\end{tabular}

The above table shows that out of 206 students 183(88.8\%) of them indicated that smart phones has made positive impact on their medical information seeking behavior which has impacted on their academic performance.

Research Question 4: What are the major problems faced by medical students in using smart phones in gathering information for their academic works?

\begin{tabular}{|c|c|c|c|c|c|c|c|c|}
\hline $\mathrm{S} / \mathrm{N}$ & Statement item & SA & A & $\mathrm{D}$ & SD & $\mathrm{F}$ & Mean & Remark \\
\hline 1 & Operational difficulties/ poor usage skill & 128 & 75 & 2 & 1 & 745 & 3.6 & Agree \\
\hline 2 & Fragility (easily damaged) & 89 & 104 & 6 & 7 & 687 & 3.3 & Agree \\
\hline 3 & Incessant virus attack & 76 & 63 & 40 & 27 & 600 & 2.9 & Agree \\
\hline 4 & High cost of data subscription & 82 & 72 & 50 & 2 & 646 & 3.1 & Agree \\
\hline 5 & $\begin{array}{l}\text { Irregular/ unstable power supply for regular } \\
\text { charging of battery on campus }\end{array}$ & 122 & 80 & 4 & - & 736 & 3.6 & Agree \\
\hline 6 & $\begin{array}{l}\text { Using smart phones have interrupted my } \\
\text { original life style. }\end{array}$ & 18 & 17 & $\begin{array}{l}16 \\
2\end{array}$ & 9 & 456 & 2.4 & Disagree \\
\hline 7 & $\begin{array}{l}\text { Lack of technical experts on repair when } \\
\text { faulty within campus }\end{array}$ & 93 & 87 & 23 & 3 & 682 & 3.3 & Agree \\
\hline 8 & Distraction via unnecessary adverts pop up & 13 & 107 & 75 & 11 & 534 & 2.5 & Agree \\
\hline 9 & $\begin{array}{l}\text { There is high risk of radiation when using } \\
\text { smart phones }\end{array}$ & 187 & 16 & 3 & - & 802 & 3.9 & Agree \\
\hline 10 & $\begin{array}{l}\text { Insecurity of usage due to high rate of theft } \\
\text { on campus }\end{array}$ & 128 & 71 & 7 & - & 739 & 3.6 & Agree \\
\hline 11 & $\begin{array}{l}\text { Distraction from unnecessary use of social } \\
\text { medical while reading }\end{array}$ & 56 & 114 & 26 & 10 & 628 & 3.0 & Agree \\
\hline
\end{tabular}


From the table above, results show that majority of respondents agreed that there is high risk of radiation when using smart phones (3.9), operation difficulties/ poor usage skills (3.6), irregular/ unstable power supply for regular charging of battery on campus (3.6), insecurity of usage due to high rate of theft on campus (3.6), lack of technical expert on campus (3.3) Fragility (easily damages) from service providers (3.1), are the major problems they encountered in using smart phones while they also disagree that smart phones have not interrupted their original life style.

\subsection{DISCUSSION OF FINDINGS}

Student responses indicate that mobile devices are potential avenues for receiving instructional materials and invaluable resource for immediate feedback and other education purposes. The result of the first research question showed that majority of the respondents own and use smart phones for gathering information for their academic work. This shows that there is very high level of awareness and use of smart phone for medical education purposes. This is in line with the findings of Vafa and Chico (2013), that there is growing awareness in ownership and use of mobile technologies in medical education by both students and the medical community.

The result of the second research question revealed that majority of the respondents use their smart phones in downloading medical app, downloading e -text books, browsing the internet, social networking, taking notes in class/ lab. These services were quite difficult to access within the university system about a decade ago. But the advent of these devices has really helped students to access them within the confines of their palms. This was not far from the findings of Davies et al (2012), who investigated how mobile information resources contribute to learning of undergraduate clinical students in the UK. The study adopted mixed methods triangulation approach using quantitative and qualitative analysis of surveys, focus group discussion and observation through usage tracking data to 387 medical students provided with a personal digital assistant (PDA) loaded with medical resources for the duration of their clinical studies. Their study result showed that PDA was an important addition to the learning ecology rather than a replacement and contextual factors impacted on use of mobile technologies both positively and negatively on medical students learning outcomes. Interruption of clinical interaction and negative resources from teachers and patients were discovered as some of the barriers encountered while using the mobile devices during their clinical practices and those students preferred a future involving smart phone platform.

The result of the third research question shows that majority of the respondents $183(88.8 \%)$ indicated that smart phones have made positive impact on their medical academic performance. The major areas smarts made tremendous impact on their academic performance were easy and fast internet access, high speed browsing, saves their time and money going to cybercafé/ college library, easy access to medical teaching and eOlearning materials/ e-text books. This is in collaboration with (Paddock 2012, Boruff and Stories, 2014). Paddock, (2012) pointed out that, there is a lot relief to the students as the smart devices within their disposal saves them the stress involved in accessing these essential services in their medical teaching, learning and research activities which were previously difficult to access. But, what stands out as an initiative to make campuses greener, is beginning to deliver other unexpected benefits, such as cost savings and improvement to the learning process itself. Boruff and Storie, (2014), opines that, these services enable medical students to find medical information on the internet, taking and presenting notes in classes and labs, reading and downloading very costly medical e-text books and journals that are ordinarily expensive to acquire. Medical students used their devices for broader range of activities that other groups, such as to find drug information, find clinical practice guideline, read point of care: information, do clinical calculations or perform differential diagnosis.

Finally, the result to the last research question, revealed that majority of the respondents indicated lack of technical experts on repairs when faulty within campus, operational difficulties/ poor usage skills, high cost of data subscription/ internet access from service provider and fragility (easily damaged). Others are: Insecurity of usage due to high rate of theft on campus, irregular/ unstable power supply for regular charging of battery on campus and distraction from unnecessary use of social media when studying were the other barriers facing the use of smart phones in medical education. This is in line with Boulos et al (2011), who noted that most of the respondents have to travel to distant places to put faulty devices in order. System and service reliability is also an important issue to take into account, firstly, due to the possible negative sensation that the application may give to the user in the case of malfunctioning and secondly, due to the physical distance between the technical maintenance teams and the users. This creates a lot of inconveniences for the respondents who find it difficult to sacrifice their time for such situation due to the tight schedule of their medical education calendar.

Boruff and Stories (2014), opine that a poor usage skill is another serious barrier bedevilling the effective use of smart phones for medical education. These are high tech digital gadgets that are often embedded with so much functionalities and it is expected of every user to have some level of understanding to make appreciable use of them, anything less than this will amount to frustration and underutilization for medical and health education. Technological, 
intellectual, access and lack of awareness were some of the possible barriers they encountered in using smart phones in seeking medical and health information.

Also, high cost of data subscription on the part of network service providers greatly impeded the effective use of smart phones by students. Most users especially students of low income families find it difficult to access internet service due to the high cost of charges and frequent network failures that leads to incessant deductions of available data. Lack of regular power supply or incessant power outages mostly common in developing countries of Africa affects the effective use of smart phones for medical and health education. Due to the high functional details embedded in smart phones, their effective use demands constant or relatively regular power supply. Thus lack or absence of this will greatly hamper the use of such high tech digital materials for adequate medical teaching, learning and research

\subsection{CONCLUSIONS AND RECOMMENDATIONS}

The study was conducted to identify the contributions of smart phones in gathering medical and health information by undergraduates in the faculty of basic sciences, college of medicine, AAU, in supporting their medical teaching, learning and research initiatives. The study revealed a growing awareness in the use of smart phones by students for accessing relevant medical and health information for educational purposes and that these devices have made tremendous impact on their access to internet, access to study materials, note taking in classes and laboratories, accessing college portals, patient care information, writing, submitting and accessing scholarly publications in ejournals etc. unfortunately on the other hand, the findings identified lack of technical support when faulty within campus, operational difficulties, poor knowledge on usage, high cost of data subscription and poor power supply as barriers militating against the use of smart phones by medical students.

Based on the findings, the researchers recommend the following:

1. The use of smartphones should be encouraged for academic work at all levels.

2. There should be deliberate periodic advancement of smartphones for better performance.

3. Smartphones technicians can be employed within campuses to repair faulty phones.

4. Nigerian Communication Commission (NCC) should monitor service providers to ensure affordable subscription rate to students.

5. Tertiary institutions should try to provide free Wifi for tertiary students.

6. Issue of poor power supply should be looked at most especially within campuses.

\section{REFERENCES}

Aina, L.O. (2002). Research in Information Sciences. An African Perspective. Ibadan: Stirling Horden Publishers.

Blumenstock,J.J. \& Eagle, N. (2010). Mobile Divides: Gender, Socio-economic Status, and Mobile Phone use in Rwanda. U.C. Berkeley School of Information Berkeley, C A 94720.

Boruff, J.T, \& Stories D. (2014). Mobile devices in Medicine: Survey of How Medical Student, Residents and Faculty Use Smart Phones and Other Mobile Devices to Find Information. Journal of Medical Library Association 102 (1) 22-30.

Boulos, M.N. K., Wheeler, S., Tavares, C \& Jones .R (2011). How Smart Phones are Changing the Face of Mobile and Participatory Healthcare: An overview, with example from Ecaalyx. Biomedical Engineering Online 10 (24), 1-4. Retrieved from: http://wwwbiomedical-engineering-online.com

Davies et .al. (2012). Mobile Medical Education (MOMED) - How mobile Information Resources Contribute to Learning for Undergraduate Clinical Students. A mixed Method Study. Biomed Central 12 (1), 1-11. Retrieved from: http://www.biomedcentral.com/ 1472-6920/12/1/prepup.

Fuxin .A.Y. (ND). Mobile Smart Phone Use in Higher Education. Retrieved From: Content://.com. $1^{\text {st }}-$ 01-2017.

Hakoama, M \& Hakoyama, S (2011), The Impact of Cell Phone Use on Social Networking and Development Among College Students. The American Association of Behavioral and Social Sciences Journal 15, 1-20.

Elogie, A.A, Ikenwe,I.J and Idubor, I. (2015). Factors influencing the adoption of smartphones by undergraduate students at Ambrose Alli University, Ekpoma, Nigeria. The Information Technologist: An International Journal of Information and Communication Technology. Vol. 12; No. 1.

Johnson, C. \& Kritsons, W.A. (2007). National School Debate: Banning Cell phones On Public School Campuses in America. National Forum of Education Administration and Supervision Journal 25(4), 1-6.

Jubien, P. (2013). Shape Shifting Smart Phones: Riding the Waves in Education, Canadian Journal of Learning and Technology, 39. 
Koh, K.C. and Wan, J.K. (2014). Medical Student Perceptions Regarding the Impact of Mobile Medical applications on Their Clinical Practice. Journal of Mobile Technology in Medicine 3(1), 46-53.

Litchfield, S. (2010). Defining the Smart phone. Retrieved From: http://www.allaboutsymbian.com/feature/item/defining-he-smartphonephp.

Mayer, R.E. \& Moreno, R. (2003). Nine Ways to Reduce Cognitive Load in Multimedia Learning. Educational Psychologists, 38, 43-53.

Paddock, C. (2012). Ipads in Health and Medicine: More than an Information Revolution. Retrieved from: http://www.marcprensky.com/writing/prensky.DigitalWatixes, Digitalimmigrants parts.pdf.

Rabiu, H., Muhammed, A.I, Umaru, Y. \& Ahmed H.T. (2016). Impact of Mobile Phone Usage on Academic Performance Among Secondary School Students in Taraba State. Nigeria. Retrieved from http://dx.doi.org/10.19044/esj.2016 vlzn/p466

Rebello, J. (2010). Global wireless Subscription Reach. Retrieve on 4-01-2017.

Rouse, M. (2013). Smart Phone Definition. Retrieve on 1 15t-01- 2017 from: searchmobilecomputing.techtarget.com

Sarwar M. \& Soomro T.R. (2013). Impact of Smart Phones on the Society. European Journal of scientific Research. Retrieved from http://www.europeanjornalofscientificreasearch.com

Taylor, A.S \& Harper, R. (2003). Talking Activity: Young People and Mobile Phone, CHI, 2001 Workshop: Mobile Communication, Understanding Users, Adoption and Design, Seattle.

Vafa,S. and Chico, D.E (2013). A Needs Assessment For Mobile Technology Use in Medical Education. International Journal of Medical Education. (4) 230- 235 Retrieved from: http://creativeeconomic.org/licenses/by/3.0

Cite this Article: Ikenwe IJ, Idhalama OU and Inegbenojie OE (2017). Empirical Look at the Use and Impact of Smart Phones by Medical Students for Laboratory/ Educational Purposes at Ambrose Alli University, Ekpoma, Edo State. Greener Journal of Educational Research, 7(4): 061-069, http://doi.org/10.15580/GJER.2017.4.061917078 